\title{
Prevalence of congenital malformations at the "les Orangers" maternity and reproductive health Hospital of Rabat: descriptive study of 470 anomalies
}

\author{
K. Forci ${ }^{1 *}$ (D, M. H. Alami ${ }^{1,2}$, E. Bouaiti ${ }^{3}$, M. Slaoui $^{4}$, A. Mdaghri Alaoui ${ }^{1,5}$ and A. Thimou Izgua ${ }^{1,6}$
}

\begin{abstract}
Background: Congenital malformations are described in about $3 \%$ of live births and $20 \%$ of stillbirths in the industrialized countries.

The prevalence of congenital anomalies in developing countries, including Morocco, is not well known at the national level.

The aim of our study is to conduct a descriptive exploratory analysis of congenital malformations cases diagnosed at the "Les Orangers" Maternity and Reproductive Health Hospital in Rabat.

Methods: We collected all the cases of congenital malformations diagnosed at the "Les Orangers" Maternity and Reproductive Health Hospital in Rabat, from January 1st, 2011 to June 31st, 2016.

Data were reported on pre-established sheets and on a registry of malformations. Total and specific prevalences were calculated for each malformation. A principal component analysis (PCA) was then conducted followed by a Varimax rotation in order to identify the different associations of malformations in our series.

Results: We registred 245 cases of congenital malformations out of a total of 43,923 recorded births; a prevalence of 5.58 per thousand births of which 19.2\% were FDIU (fetal deaths in utero).

A polymalformative syndrome was found in $26.5 \%$ of cases which makes a total number of 470 anomalies. The musculoskeletal anomalies predominate with a rate of $33 \%$, followed by neurological abnormalities $18 \%$, of whom $31 \%$ were hydrocephalus, 26.2\% anencephaly, and 20.24\% spina bifida. Malformations of the eye, ear, face and neck were described in $12 \%$ of the cases, while genetic abnormalities were observed in $8,5 \%$ of which $87.5 \%$ represented Down syndrome.

The antenatal diagnosis of congenital malformations was performed in $28.6 \%$ of cases.

Conclusions: Our study provides a general overview of the epidemiological situation related to different types of congenital anomalies for a specific area in Morocco.

It represents a database that should be complemented by other multicenter studies and the implementation of a (Continued on next page)
\end{abstract}

\footnotetext{
* Correspondence: Docteurforcikhenata@gmail.com

'Congenital anomalies research team, Faculty of Medicine and Pharmacy of

Rabat, University Mohamed V Rabat, B.P: 174 Downtown-Rabat, Rabat,

Morocco

Full list of author information is available at the end of the article
}

(c) The Author(s). 2020 Open Access This article is licensed under a Creative Commons Attribution 4.0 International License, which permits use, sharing, adaptation, distribution and reproduction in any medium or format, as long as you give appropriate credit to the original author(s) and the source, provide a link to the Creative Commons licence, and indicate if changes were made. The images or other third party material in this article are included in the article's Creative Commons licence, unless indicated otherwise in a credit line to the material. If material is not included in the article's Creative Commons licence and your intended use is not permitted by statutory regulation or exceeds the permitted use, you will need to obtain permission directly from the copyright holder. To view a copy of this licence, visit http://creativecommons.org/licenses/by/4.0/ The Creative Commons Public Domain Dedication waiver (http://creativecommons.org/publicdomain/zero/1.0/) applies to the data made available in this article, unless otherwise stated in a credit line to the data. 
(Continued from previous page)

national registry to determine the prevalence of congenital malformations at a national level.

Keywords: Congenital malformation, Prevalence, Association, Antenatal diagnosis, Morocco

\section{Background}

Malformations are often described as congenital defects whether they are diagnosed at birth or later. Thus, the real defects or "primary defects" should be distinguished from distortions and disruptions that are secondary to an extrinsic factor and called "secondary defects". This distinction is essential to establishing genetic counseling, as it allows evaluating the risk of malformation occurrence or recurrence and proposing appropriate prevention.

A congenital malformation $(\mathrm{CM})$ is a morphological abnormality that results from an abnormal development process during the formation of the embryo or fetus. Depending on their types, locations and sizes, malformations can cause functional, psychological, or aesthetic disorders that presently affect more than 8 out of every 1000 children $[1,2]$.

Congenital malformations account for about $3 \%$ of live births and $20 \%$ of stillbirths. In industrialized countries they represent a frequent cause of infant mortality, morbidity and disability [3-6].

According to the WHO (World Health Organization), about half of congenital anomalies cannot be attributed to a specific cause. Some risk factors or causes are often associated and there are three etiological groups: [7].

- Genetic intrinsic causes (10-15\%): chromosomal, genetic or epigenetic;

- Extrinsic environmental causes (10-15\%): infectious agents (rubella, toxoplasmosis, cytomegalovirus), physical (ionizing radiation, hyperthermia), medicinal (isotretinoin, thalidomide, antiepileptics), metabolic (maternal diabetes, folic acid deficiency), toxic (tobacco, fetal alcohol syndrome), mechanical (oligoamnios);

- Multifactorial causes (20-25\%)

Congenital malformations are one of the leading causes of morbidity and neonatal mortality in all developing countries in general and in Morocco in particular. According to the results of the last National Survey of Population and Family Health (ENPSF) 2017-2018, the neonatal mortality rate in Morocco is 13.56 per thousand live births with an infant mortality rate (less than 1 year) of $18 \%$ [8]. Unfortunately, the prevalence of congenital malformations and their causes are not yet established at the national level due to the lack of a nationwide congenital malformations monitoring system.

Consequently, the aim of the present study is to conduct a descriptive exploratory analysis of CM cases diagnosed at "Les Orangers" Maternity and Reproductive Health Hospital in Rabat.

\section{Methods \\ Study design}

This is a descriptive epidemiological study of CM cases diagnosed prenatally by obstetrical ultrasound and / or at birth during a routine clinical examination of all newborn infants in the "Les Orangers" Maternity Hospital and Reproductive Health of Rabat, Morocco during the period from January 1st, 2011 to June 31st, 2016.

This hospital is a level 3-facility with an average annual delivery rate of 8000 . It receives parturient/laboring women from all over Morocco. In addition, it ensures the monitoring of high risk or as well as normal pregnancies by carrying out antenatal checkups and obstetric ultrasounds.

All pregnant women whose fetuses or newborns had a malformation were included, regardless of the term or outcome of the pregnancy.

Cases where the malformation was suspected on obstetrical ultrasound but not confirmed at birth were excluded as were the cases of refusal to participate in the survey.

Parents were informed about the terms and objectives of the study and their consent was obtained. A significant proportion of women included in our study were illiterate and for cultural reasons they prefer to give an oral agreement without signing. At least 3 persons from the medical have witnessed each oral consent. Furthermore, oral explanations and a written document describing the information relevant to their consent and the contact details of the researcher were provided to each patient. The ethics committee accepted this procedure.

\section{Data collection}

The collection of information was carried out by a doctor and reported on pre-established sheets and on "Les Orangers" Maternity's Malformations Register.

To determine the prevalence, we opted for the international definitions used by EUROCAT and the ICBDSR:

- Total prevalence: total number of cases (live births, stillbirths and medical interruptions of pregnancy) divided by the total number of births (live births and stillbirths). 
- Prevalence of live births: number of children born alive with the anomaly divided by the total number of live births $[9,10]$.

To classify the malformations we used the following definitions of malformation types:

- "Isolated" malformation: any malformation not associated with a chromosomal abnormality or other major abnormality of another system.

- Polymalformations: when there is an association of at least two malformations. They can correspond to three different situations [11]:

1) A sequence: is a set of anomalies resulting from a single anomaly or a mechanical factor: For example the oligoamnios sequence or Potter's sequence, following a lack of amniotic fluid.

2) A malformative syndrome: is a set of unrelated abnormalities, all derived from the same cause and not corresponding to a sequence, e.g., Down syndrome.

3) An association: is the unplanned occurrence of at least two unrecognized malformations as a sequence or syndrome, e.g., VACTER syndrome, acronym for "vertebral, anal, cardiac, tracheal, esophageal, radial and / or renal malformations".

\section{Statistical analysis}

Data entry and statistical analysis was carried out using SPSS.18.0 software. Total and specific prevalences were calculated for each malformation. Principal component analysis (PCA) followed by Varimax rotation was performed. The selected factors had a true value greater than 1.25. The items retained within each factor had a value greater than or equal to 0.40 within the factor and a value below 0.40 within the other factors. A forced structure with three inter-correlated factors was selected for each malformation.

\section{Results}

During the study period, 43,923 births were included, of which 245 cases had one or more congenital malformations, which represents a prevalence of 5.58 per thousand births (or 55.8 per 10,000 births). Of these cases, $96.7 \%$ had one or more clinically visible malformations, $51.9 \%$ were males and $43.5 \%$ were females with a sex ratio of 1.19 .

A polymalformative syndrome was found in $26.5 \%$ of cases which explains why the total number of identified congenital malformations, with 470 anomalies, exceeds the number of patients.

Within these 470 reported CMs, musculoskeletal malformations accounted for $33 \%$ of cases followed by neurological malformations with a rate of $18 \%$, and then abnormalities of the eye, ear, face and neck at $12 \%$. Genetic abnormalities represented $8.5 \%$. (The different types and subtypes of recorded malformations are summarized in Tables 1 and 2).

Malformation diagnosis was performed in more than two thirds of cases (71.4\%) at birth during a systematic newborn infant's clinical examination.

The antenatal diagnosis, which represents $28.6 \%$ of cases, was performed mainly in the second and third trimesters with a proportion of respectively $47 \%$ (33 cases) and $48.5 \%$ ( 34 cases). The ultrasound diagnosis during the first trimester only covered $5.7 \%$ (4 cases).

The factorial analysis has identified a seven-factor structure (associations of malformations) accounting for $21.28 \%$ of the overall variance (Table 3 ). The first three associations accounted for more than $50 \%$ of the total variance.

- The first factor is an association of congenital malformations corresponding to Trisomy 8, pelvic kidney, microphthalmia, sacral agenesis, epidermal sinus, agenesis of nose cartilage and clubfoot.

- The second factor is an association of congenital malformations corresponding to craniosynostosis, funnel chest, limb asymmetry, scoliosis, cleft palate and ureteral dilatation.

- The third factor is an association of congenital malformations corresponding to invisible bladder, absence of thalami, thin thorax, hyperflexion limbs, cardiomegaly, amniotic flanges and polycystic kidney.

\section{Discussion}

In the present study, a prevalence of 5.58 per thousand births $(0.56 \%$ or 55.8 per 10,000 births) was reported. This prevalence is consistent with that of other African countries.

Indeed, a retrospective analytical study carried out in the city of Lubumbashi, Congo between 2010 and 2011 across 11 maternity clinics showed a prevalence of 58.4 per 10,000 births $(0.58 \%)$ [13]. A similar prevalence $(0.57 \%)$ was also found in a multicenter prospective study conducted at Clinical Universities of Kinshasa [14].

In addition, a study conducted in Egypt between 1995 and 2009 showed a frequency of CMs of $2 \%$ [15].

In developed countries, where congenital anomalies are systematically reported in national registries, the prevalence of congenital malformations is 6 times higher than the one we have reported in our study. In France, for example, the estimated prevalence of congenital malformations at birth is $3-4 \%$ [16] while it stands at $3-5 \%$ in Canada and the United States [17, 18].

Thus, the prevalence reported in our study is probably below the real value due to possible under-reporting of 
Table 1 The different types of congenital malformations according to the International Classification ICD-10 [12]

\begin{tabular}{ll}
\hline Types of congenital malformations according to the International Classification ICD-10 & Prevalence compared to all malformations in percentage \\
\hline Q00-Q07 Congenital malformations of the nervous system & 18 \\
Q10-Q18 Congenital malformations of eye, ear, face and neck & 12 \\
Q20-Q28 Congenital malformations of the circulatory system & 8 \\
Q30-Q34 Congenital malformations of the respiratory system & 1 \\
Q35-Q37 Cleft lip and cleft palate & 4,5 \\
Q38-Q45 Other congenital malformations of the digestive system & 4 \\
Q50-Q64 Congenital malformations of genital organs & 7,5 \\
Q65-Q79 Congenital malformations and deformations of the musculoskeletal system & 33 \\
Q80-Q89 Other congenital malformations & 4 \\
Q90-Q99 Chromosomal abnormalities, not elsewhere classified & 8,5
\end{tabular}

International Statistical Classification of Diseases and Related Health Problems 10th Revision (ICD-10)-WHO Version for; 2017

malformations in addition to the fact that some late-onset malformations, posterior to neonatal period, were not accounted for. This observation is found in a majority of studies carried out in developing countries $[19,20]$.

The most frequently reported malformations in our series were musculoskeletal abnormalities, CMs of nervous system and CMs of eye, ear, face and neck. These 3 types of malformations represent $60 \%$ of reported cases.

Musculoskeletal abnormalities were the most frequently reported with a rate of $33 \%$ (equivalent to 35 per 10,000 total births), of which $17.4 \%$ of clubfoot, $7.7 \%$ of omphalocele, $7.1 \%$ of supernumerary fingers, followed by short limbs with a rate of $6.4 \%$, and laparoschisis $5.1 \%$.

The predominance of musculoskeletal abnormalities was also reported in other countries [21, 22].

A study by Sakar et al. in India reported a similar prevalence of musculoskeletal abnormalities at 33\% followed by abnormalities of digestive and central nervous systems [23].

In Egypt, the rate of musculoskeletal abnormalities is $8.82 \%(1.8 / 1000)$ [15].

A study by Dolk et al. in Europe indicated that limb abnormalities were more frequent (38 per 10,000 births) than neurological one (23 per 10,000 births) [24].

In Canada, the prevalence of limb malformations was estimated at 3.5 per 10,000 total births in 2007, and the prevalence of laparoschisis was 4.4 per 10,000 total births in 2009 [17].

$\mathrm{CM}$ of the nervous system was the second most reported in our study with a percentage of $18 \%$ (19 per 10, 000 births). Out of these reported cases, $31 \%$ were of hydrocephalus (5.9 per 10,000 total births), $26.2 \%$ of anencephaly (versus 5 per 10,000 total births), 20.2\% spina bifida (3.8 per 10,000 total births).

However some studies, such as those in Irak, India, Turkey and Ethiopia [20, 25-27], reported that neurological malformations ranked first with higher prevalence.
Similarly, a study conducted in Egypt between 1995 and 2009 reported a higher prevalence of neurological malformations at a rate of 55/10,000 and a lower prevalence of musculoskeletal abnormalities at 18/10,000 [15].

These differences in reported prevalence rates between studies reflect significant differences between populations, the environment and health policies of each country. They also reflect difference in collection period, recruitment mode or definition of congenital malformation cases.

In our study, the prevalence of neural tube defects is reported at 10 per 10,000 total births. This prevalence varies between countries from a low 4.1 per 10,000 births in Canada [17] to a high 12.8 per 10,000 births in England and Wales [28] while, in the European Union, the current prevalence of neural tube defects (NTD) was estimated at $10.8(9.80-10.36)$ per 10,000 births between 2011 and 2017 according to the latest results published by EUROCAT [29].

The prevalence remains high in developing countries while it has gone down significantly in countries which implemented NTD prevention policies including folic acid supplementation and prenatal NTD screening and pregnancy interruption for severe cases [17].

In Morocco, the ministry of health started a folic acid supplementation strategy in 2008 according to a protocol which specifies a supplementation of $400 \mu \mathrm{g}$ of vitamin B9 to parturient women while for epileptic undertreatment women (sodium valproate, carbamazepine) and women with a history of neural tube closure abnormalities (an affected newborn or family cases) the protocol specifies a $5 \mathrm{mg} /$ day dose 2 months prior to conceiving and during the first 3 months of pregnancy.

Genetic abnormalities represent $8.5 \%$ (9 per 10,000 total births), $87.5 \%$ of which are Down syndrome ( 8 per 10,000 total births). In Egypt, these genetic abnormalities represent $25 \%$ (5,1/1000 total births), $74.49 \%$ of which are Down syndrome [15]. 
Table 2 Prevalence of types and subtypes of congenital malformations identified at "Les Orangers" Maternity and Reproductive Health Hospital of Rabat, Morocco

\begin{tabular}{|c|c|c|c|}
\hline Types and subtypes of congenital malformations according to classification (ICD-10) & No./470 & $\%$ & Total prevalence per 10,000 live births \\
\hline \multicolumn{4}{|l|}{ Q00-Q07 Congenital malformations of the nervous system } \\
\hline Hydrocephalus (Q03.9) & 26 & 31 & 5,9 \\
\hline Anencephaly (Q00) & 22 & 26,2 & 5 \\
\hline Spina-bifida (Q05.9) & 17 & 20,24 & 3,8 \\
\hline Encephalocele (Q01.9) & 5 & 6 & 1,14 \\
\hline Microcephaly (Q02) & 4 & 4,76 & 0,9 \\
\hline Holoprosencephaly (Q04.2) & 4 & 4,76 & 0,9 \\
\hline Dandy Walker syndrome (Q03.1) & 2 & 2,4 & 0,45 \\
\hline Arnold Chiari syndrome (Q07.0) & 1 & 1,2 & 0,2 \\
\hline Facial paralysis (Q07.8) & 1 & 1,2 & 0,2 \\
\hline Agenesis of corpus callosum (Q04.0) & 1 & 1,2 & 0,2 \\
\hline Absence of Thalami ${ }^{a}$ & 1 & 1,2 & 0,2 \\
\hline Total & 84 & 100.00 & 19 \\
\hline \multicolumn{4}{|l|}{ Q10-Q18 Congenital malformations of the eye, ear, face \& neck } \\
\hline Craniofacial dysmorphism ${ }^{\mathrm{a}}$ & 29 & 51,78 & 6,6 \\
\hline Short neck ${ }^{\mathrm{a}}$ & 6 & 10,7 & 1,3 \\
\hline Retrognatism $^{\mathrm{a}}$ & 6 & 10,7 & 1,3 \\
\hline Low-set ears (Q17.4) & 6 & 10,7 & 1,3 \\
\hline Exophtalmia (=Macrophtalmos) (Q11.3) & 3 & 5,35 & 0,7 \\
\hline Microphtalmos (Q11.2) & 1 & 1,8 & 0,2 \\
\hline Congenital glaucoma (Q15.0) & 1 & 1,8 & 0,2 \\
\hline Frontal bossing ${ }^{\mathrm{a}}$ & 1 & 1,8 & 0,2 \\
\hline congenital absence of auricle (Q16.0) & 1 & 1,8 & 0,2 \\
\hline Canines $^{a}$ & 1 & 1,8 & 0,2 \\
\hline Gum tooth ${ }^{\mathrm{a}}$ & 1 & 1,8 & 0,2 \\
\hline Total & 56 & 100.00 & 12,7 \\
\hline \multicolumn{4}{|l|}{ Q20-Q28 Congenital malformations of the circulatory system } \\
\hline Congenital valve malformation ${ }^{a}$ & 10 & 26,31 & 2,2 \\
\hline Anasarca fetoplacental ${ }^{a}$ & 7 & 18,42 & 1,6 \\
\hline Cardiomegaly ${ }^{\mathrm{a}}$ & 5 & 13,15 & 1,1 \\
\hline Cystic hygroma $^{a}$ & 5 & 13,15 & 1,1 \\
\hline Single umbilical artery (Q27.0) & 4 & 10,52 & 0,9 \\
\hline Hydrothorax ${ }^{a}$ & 2 & 5,3 & 0,45 \\
\hline Laevocardia (Q24.1) & 1 & 2,63 & 0,2 \\
\hline Tetralogy of Fallot (Q21.3) & 1 & 2,63 & 0,2 \\
\hline Congenital malformation of heart, unspecified (Q24.9) & 1 & 2,63 & 0,2 \\
\hline Single umbilical artery (Q27.0) & 1 & 2,63 & 0,2 \\
\hline 2 arteries +2 veins $^{a}$ & 1 & 2,63 & 0,2 \\
\hline Total & 38 & 100.00 & 8,6 \\
\hline \multicolumn{4}{|l|}{ Q30-Q34 Congenital malformations of the respiratory system } \\
\hline Agenesis of nose cartilage (Q30.1) & 2 & 40 & 0,45 \\
\hline Hypoplasia and dysplasia of lung (Q33.6) & 2 & 40 & 0,45 \\
\hline Agenesis of lung (Q33.3) & 1 & 20 & 0,2 \\
\hline
\end{tabular}


Table 2 Prevalence of types and subtypes of congenital malformations identified at "Les Orangers" Maternity and Reproductive Health Hospital of Rabat, Morocco (Continued)

\begin{tabular}{|c|c|c|c|}
\hline Types and subtypes of congenital malformations according to classification (ICD-10) & No./470 & $\%$ & Total prevalence per 10,000 live births \\
\hline Total & 5 & 100.00 & 1,1 \\
\hline \multicolumn{4}{|l|}{ Q35-Q37 Cleft lip and cleft palate } \\
\hline Cleft palate with cleft lip (Q37.-) & 9 & 42,86 & 2 \\
\hline Cleft lip (Q36.-) & 7 & 33,33 & 1,6 \\
\hline Cleft palate (Q35.-) & 3 & 14,3 & 0,6 \\
\hline Alveolar cleft ${ }^{\mathrm{a}}$ & 1 & 4,76 & 0,2 \\
\hline Velopalatine cleft $^{\mathrm{a}}$ & 1 & 4,76 & 0,2 \\
\hline Total & 21 & 100.00 & 4,8 \\
\hline \multicolumn{4}{|l|}{ Q38-Q45 Other congenital malformations of the digestive system } \\
\hline Atresia of oesophagus NOS (Q39.0) & 6 & 33,33 & 1,3 \\
\hline Hepatomegaly (Q44.7) & 3 & 16,7 & 0,6 \\
\hline Imperforate anus (Q42.3) & 2 & 11,11 & 0,45 \\
\hline Antal malformation (Q43.9) & 2 & 11,11 & 0,45 \\
\hline Congenital malformation of mouth NOS (Q38.6) & 1 & 5,55 & 0,2 \\
\hline High arched palate (Q38.5) & 1 & 5,55 & 0,2 \\
\hline Macroglossia (Q38.2) & 1 & 5,55 & 0,2 \\
\hline Glossoptosis $^{a}$ & 1 & 5,55 & 0,2 \\
\hline Congenital dilatation of the colon (Q43.9) & 1 & 5,55 & 0,2 \\
\hline Total & 18 & 100.00 & 4,1 \\
\hline \multicolumn{4}{|l|}{ Q50-Q56 Congenital malformations of genital organs } \\
\hline Hypospadias (Q54.9) ${ }^{\mathrm{a}}$ & 7 & 28 & 1,6 \\
\hline Micropenis (Q55.6) & 7 & 28 & 1,6 \\
\hline Ambiguous genitalia (Q56.4) & 6 & 24 & 1,3 \\
\hline Cryptorchism (Q53.9) & 3 & 12 & 0,6 \\
\hline Invisible clitoris (Q52.6) & 1 & 4 & 0,2 \\
\hline Congenital malformation of female genitalia (Q52.9) & 1 & 4 & 0,2 \\
\hline Total & 25 & 100.00 & 5,7 \\
\hline \multicolumn{4}{|l|}{ Q60-Q64 Congenital malformations of the urinary system } \\
\hline Polycystic kidney (Q61.3) & 2 & 20 & 0,45 \\
\hline Ureterohydronephrosis (Q62.-) & 2 & 20 & 0,45 \\
\hline Epispadias (Q64.0) & 2 & 20 & 0,45 \\
\hline Absence of bladder (Q64.5) & 2 & 20 & 0,45 \\
\hline Congenital dilatation of ureter (Q62.2) & 1 & 10 & 0,2 \\
\hline Congenital displaced kidney (Q63.2) & 1 & 10 & 0,2 \\
\hline Total & 10 & 100.00 & 2,27 \\
\hline \multicolumn{4}{|l|}{ Q65-Q79 Congenital malformations and deformations of the musculoskeletal system } \\
\hline Clubfoot (Q66.8) & 27 & 17,4 & 6 \\
\hline Omphalocele (Q79.2) & 12 & 7,7 & 2,7 \\
\hline Accessory fingers (Q69.0) & 11 & 7,1 & 2,5 \\
\hline Reduced limbs (Q73.8) & 10 & 6,4 & 2,3 \\
\hline Gastroschisis (Q79.3) & 8 & 5,1 & 1,8 \\
\hline Chondrodysplasia punctata (Q77.3) & 6 & 3,9 & 1,3 \\
\hline Talipes equinovarus (Q66.0) & 5 & 3,2 & 1,1 \\
\hline
\end{tabular}


Table 2 Prevalence of types and subtypes of congenital malformations identified at "Les Orangers" Maternity and Reproductive Health Hospital of Rabat, Morocco (Continued)

\begin{tabular}{|c|c|c|c|}
\hline Types and subtypes of congenital malformations according to classification (ICD-10) & No./470 & $\%$ & Total prevalence per 10,000 live births \\
\hline Macrocephaly (Q75.3) & 5 & 3,2 & 1,1 \\
\hline Prune Belly syndrome (Q79.4) & 5 & 3,2 & 1,1 \\
\hline Syndactyly (Q70.-) & 4 & 2,6 & 0,9 \\
\hline Toe agenesis $^{a}$ & 4 & 2,6 & 0,9 \\
\hline Feet valgus (Q66.6) & 3 & 1,9 & 0,7 \\
\hline Clinodactyly ${ }^{a}$ & 3 & 1,9 & 0,7 \\
\hline Fingers agenesis $^{a}$ & 3 & 1,9 & 0,7 \\
\hline Congenital anomaly of limb(s) (Q74.9) & 3 & 1,9 & 0,7 \\
\hline Thanatophoric dysplasia ${ }^{a}$ & 3 & 1,9 & 0,7 \\
\hline Craniosynostosis (Q75.0) & 3 & 1,9 & 0,7 \\
\hline Hypertelorism (Q75.2) & 2 & 1,3 & 0,4 \\
\hline Hyperlaxity ligament ${ }^{a}$ & 2 & 1,3 & 0,4 \\
\hline Congenital absence of limbs (Q73.0) & 2 & 1,3 & 0,4 \\
\hline Forearm agenesis $^{\mathrm{a}}$ & 2 & 1,3 & 0,4 \\
\hline Foot agenesis $^{a}$ & 2 & 1,3 & 0,4 \\
\hline Limbs in hyperflexion ${ }^{a}$ & 2 & 1,3 & 0,4 \\
\hline Limbs asymmetry $^{a}$ & 2 & 1,3 & 0,4 \\
\hline Congenital dislocation of hip (Q65.2) & 2 & 1,3 & 0,4 \\
\hline Scoliosis (Q67.5) & 2 & 1,3 & 0,4 \\
\hline Caudal regression syndrome ${ }^{a}$ & 2 & 1,3 & 0,4 \\
\hline Diaphragmatic hernia (Q79.0) & 2 & 1,3 & 0,4 \\
\hline Narrow thorax (Q67.8) & 2 & 1,3 & 0,4 \\
\hline Amniotic bands ${ }^{a}$ & 1 & 0,64 & 0,2 \\
\hline Microdactyly ${ }^{a}$ & 1 & 0,64 & 0,2 \\
\hline Hand agenesis $^{\mathrm{a}}$ & 1 & 0,64 & 0,2 \\
\hline Phalanges agenesis ${ }^{a}$ & 1 & 0,64 & 0,2 \\
\hline Thumb hypoplasia ${ }^{a}$ & 1 & 0,64 & 0,2 \\
\hline Club hand ${ }^{a}$ & 1 & 0,64 & 0,2 \\
\hline Bone growth ${ }^{a}$ & 1 & 0,64 & 0,2 \\
\hline Spine agenesis ${ }^{a}$ & 1 & 0,64 & 0,2 \\
\hline Sarcum agenesis $^{\mathrm{a}}$ & 1 & 0,64 & 0,2 \\
\hline Parieto-occipital bone agenesis ${ }^{a}$ & 1 & 0,64 & 0,2 \\
\hline Congenital funnel chest (Q67.6) & 1 & 0,64 & 0,2 \\
\hline Malformation of ribs (Q76.6) & 1 & 0,64 & 0,2 \\
\hline Thin thorax (Q67.8) & 1 & 0,64 & 0,2 \\
\hline Asymetric thorax (Q76.9) & 1 & 0,64 & 0,2 \\
\hline Deformed thorax (Q76.9) & 1 & 0,64 & 0,2 \\
\hline Expanded Thorax (Q67.8) & 1 & 0,64 & 0,2 \\
\hline Total & 155 & 100.00 & 35 \\
\hline \multicolumn{4}{|l|}{ Q80-Q89 Other congenital malformations } \\
\hline Ichtyosis vulgaris (Q80.0) & 3 & 16,7 & 0,7 \\
\hline Cervico-facial hemolymphangioma ${ }^{a}$ & 2 & 11,11 & 0,4 \\
\hline Congenital splenomegaly ${ }^{a}$ & 2 & 11,11 & 0,4 \\
\hline
\end{tabular}


Table 2 Prevalence of types and subtypes of congenital malformations identified at "Les Orangers" Maternity and Reproductive Health Hospital of Rabat, Morocco (Continued)

\begin{tabular}{|c|c|c|c|}
\hline Types and subtypes of congenital malformations according to classification (ICD-10) & No./470 & $\%$ & Total prevalence per 10,000 live births \\
\hline Alopecia (Q84.0) & 1 & 5,55 & 0,2 \\
\hline Naevus (Q82.5) & 1 & 5,55 & 0,2 \\
\hline Epidermal sinus ${ }^{a}$ & 1 & 5,55 & 0,2 \\
\hline Depigmentation $^{a}$ & 1 & 5,55 & 0,2 \\
\hline Situs inversus (Q89.3) & 1 & 5,55 & 0,2 \\
\hline Umbilical cord membrane detachment ${ }^{\mathrm{a}}$ & 1 & 5,55 & 0,2 \\
\hline Pierre Robin syndrome (Q87.0) & 1 & 5,55 & 0,2 \\
\hline Acardiac fetus $^{\mathrm{a}}$ & 1 & 5,55 & 0,2 \\
\hline Absence of gluteal fold ${ }^{a}$ & 1 & 5,55 & 0,2 \\
\hline Cyclopia (Q87.0) & 1 & 5,55 & 0,2 \\
\hline Ombilical hernia $^{a}$ & 1 & 5,55 & 0,2 \\
\hline Total & 18 & 100.00 & 4 \\
\hline \multicolumn{4}{|l|}{ Q90-Q99 Chromosomal abnormalities } \\
\hline Down syndrome (=Down syndrome) (Q90.-) & 35 & 87,5 & 8 \\
\hline Trisomy $13(\mathrm{Q} 91.7)$ & 2 & 5 & 0,4 \\
\hline Trisomy 18 (Q91.3) & 1 & 2,5 & 0,2 \\
\hline Trisomy 8 (Q92.1) & 1 & 2,5 & 0,2 \\
\hline Senior Loken syndrome ${ }^{a}$ & 1 & 2,5 & 0,2 \\
\hline Total & 40 & 100.00 & 9 \\
\hline
\end{tabular}

No Number of cases, \% percentage

${ }^{a}$ Congenital malformations not found in the ICD-10 classification

The prevalence of Down syndrome in our study is lower than those reported by others. Indeed, A study conducted in the Rhône-Alpes region over the 19812009 period showed a prevalence of 28.7 per 10,000. In addition, a study covering the population of Paris region between 1981 and 2007 estimated the total prevalence of Down syndrome at 30.6 per 10,000 while the prevalence among live births was 8.9 per 10,000 ; a difference is mainly due to prenatal screening and medical termination of pregnancy (MTP).

The high prevalence of Down syndrome in developed country is attributable to the advanced maternal age at procreation and early screening policies [30].

The screening for Down syndrome is not generalized in Morocco which does not have a chromosomal screening policy in place. In addition, pregnancy interruption is not legally permitted.

The antenatal screening for congenital malformations is not systematic in developing countries, including Morocco, as it is not integrated in national health programs. This explains the low rate of antenatal diagnosis in our study which stands at $28.6 \%$ of cases, of which $5.7 \%$ (4 cases) were diagnosed in the 1st trimester, $47 \%$ (33 cases) in the 2nd trimester and $48.5 \%$ in the 3rd trimester.

The antenatal diagnoses performed during the 3rd trimester a related to pregnant women who were initially under the care of other health structures where no early screening was carried out, in addition to women who only sought medical care when they reached their 3rd trimester.

This delay in antenatal diagnosis of congenital malformations is also reported in other studies covering developing countries with, for example, a median gestational age of 31 weeks in Saudi Arabia and 32 weeks in Kenya $[31,32]$.

In more than two thirds of cases $(71.4 \%)$, the diagnosis was made at birth during the systematic clinical examination of newborn infants.

In our study, $26.5 \%$ of births with malformation presented a polymalformative syndrome. Seven groups of malformation associations were identified through principal component analysis. These associations can explain $21 \%$ of the malformation variability in the studied population. The 3 main associations represent more than $50 \%$ of the total variance. These 3 associations include, among other malformations, the VACTERL/VATER combination, a group of congenital malformations including vertebral "V", anorectal "A", cardiovascular "C", tracheo-esophageal "TE", renal " $\mathrm{R}$ " and limbs " $\mathrm{L}$ ".

The diagnosis of VACTERL association can only be confirmed once at least 3 of the above-mentioned congenital malformations are identified in a patient [33, 34]. 
Table 3 Analysis of congenital malformations profiles detected at the "Les Orangers" Maternity and Reproductive Health Hospital, Rabat, Morocco

\begin{tabular}{|c|c|c|c|}
\hline Profile & Congenital malformations & $\%$ of variance & $\%$ cumulated \\
\hline 1 & $\begin{array}{l}\text { - Trisomy } 8 \\
\text { - Ectopic kidney } \\
\text { - Microphthalmia } \\
\text { - Sarcum agenesis } \\
\text { - Epidermal sinus } \\
\text { - Agenesis of nose cartilage } \\
\text { - Clubfoot }\end{array}$ & 4,62 & 4,62 \\
\hline 2 & $\begin{array}{l}\text { - Craniosynostosis } \\
\text { - Funnel chest } \\
\text { - Limbs asymmetry } \\
\text { - Scoliosis } \\
\text { - Cleft palate } \\
\text { - Congenital dilatation of ureter }\end{array}$ & 3,36 & 7,98 \\
\hline 3 & $\begin{array}{l}\text { - Invisible bladder } \\
\text { - Absence of thalami } \\
\text { - Thin thorax } \\
\text { - Hyperflexion of limbs } \\
\text { - Cardiomegaly } \\
\text { - Amniotic band } \\
\text { - Polycystic kidney }\end{array}$ & 2,9 & 10,88 \\
\hline 4 & $\begin{array}{l}\text { - Thin thorax } \\
\text { - Cranio-facial dysmorphia } \\
\text { - Microdactyly } \\
\text { - Short limbs }\end{array}$ & 2,8 & 13,68 \\
\hline 5 & $\begin{array}{l}\text { - Gingival hypertrophy } \\
\text { - Macroglossia } \\
\text { - Limbs malformation } \\
\text { - Ichtyosis } \\
\text { - Exophtalmia } \\
\text { - Dandy Walker syndrome }\end{array}$ & 2,7 & 16,38 \\
\hline 6 & $\begin{array}{l}\text { - Acardiac fetus } \\
\text { - Glossoptosis } \\
\text { - Pierre Robin syndrome } \\
\text { - Retrognatism }\end{array}$ & 2,5 & 18,88 \\
\hline 7 & $\begin{array}{l}\text { - Canines } \\
\text { - Deformed thorax } \\
\text { - Hypertelorism } \\
\text { - Retrognatism } \\
\text { - Low-set ears }\end{array}$ & 2,4 & 21,28 \\
\hline
\end{tabular}

$\%=$ percentage

\section{Study limitations}

This study allowed us to estimate the prevalence of congenital malformations in the case of Morocco. However, this result is probably understating the reality of the national epidemiological situation since the malformation census is not systematically performed throughout the country. In addition, health programs have not integrated routine prenatal screening for $\mathrm{CM}$ and do not consider this problem a priority at this time. Moreover, some late-onset malformations, posterior to neonatal period, will not be counted in the census.

Finally, the insufficient description of some congenital malformation cases lead to a general under-reporting of malformations.

\section{Conclusion}

The present study evaluated the prevalence of CMs at the "Les Orangers" Maternal and Reproductive Health Hospital in Rabat, and determined the different types and existing associations of these malformations between January 1st 2011 and June 31st 2016.

It represents an epidemiological database that should be complemented by other multicenter studies to determine the prevalence of congenital malformations at a national level.

Indeed, it is a imperative to ensure the monitoring of CMs and the accurate evaluation of their general prevalence and distribution in order to assess the burden on the population as well as the health system and select the appropriate preventive measures.

Furthermore, the registration and monitoring of CMs in our country should be established as a whole program including a congenital anomalies registry as part of the national health information system and a teratovigilance network. This will allow to consider a national and/or regional strategy for antenatal diagnosis, genetic counseling and prevention of CMs. Additionally, it will enable a better management of newborns with congenital anomalies from birth.

\begin{abstract}
Abbreviations
CM: Congenital malformations; WHO: World health organization; ENPSF: National Survey of Population and Family Health; EUROCAT: European surveillance of congenital anomalies; ICBDSR: International clearinghouse for birth defects surveillance and research; VACTERNATER: Acronym for vertebral, anal, cardiac, tracheal, esophageal, radial, and/or renal malformations; PCA: Principal component analysis; FDIU: Fetal death in-utero; CDC: Centers for Disease Control and Prevention; NTDs: Neural tube defects; MTP: Medical termination of pregnancy; Cl: Confidence interval; ICD: International classification of diseases
\end{abstract}

\section{Acknowledgments}

We would like to thank everyone who has contributed to this study.

\section{Authors' contributions}

ATI was responsible for the study concept and design. KF coordinated the study and interviewed the parents. KF and EB analyzed the data. KF led the drafting of this manuscript, with input from all authors. ATI and MHA supervised analysis of the data and contributed to the writing. MS contributed to the revision of English. ATI, MHA, EB, MS and AMA contributed to revision and final approval of the manuscript. All the authors have approved the present version of the manuscript.

\section{Funding}

Not applicable.

\section{Availability of data and materials}

Data is available upon reasonable request.

\section{Ethics approval and consent to participate}

The Ethical Committee of Biological Research, Faculty of Medicine and Pharmacy - Rabat, approved the study. The oral consent to participate was obtained from the parents.

\section{Consent for publication}

Not applicable.

Competing interests

The authors declare that they have no competing interests. 


\section{Author details}

${ }^{1}$ Congenital anomalies research team, Faculty of Medicine and Pharmacy of Rabat, University Mohamed V Rabat, B.P: 174 Downtown-Rabat, Rabat, Morocco. "2"Les Orangers" Maternity and Reproductive Health Hospital of Rabat, CHU IBN SINA, Rabat, Morocco. ${ }^{3}$ Laboratory of biostatistics, clinical \& epidemiological research, Faculty of Medicine and Pharmacy of Rabat, University Mohamed V, Rabat, Morocco. ${ }^{4}$ Faculty of Medicine and Pharmacy of Rabat, University Mohamed V, Rabat, Morocco. ${ }^{5}$ Dysmorphology Unit and Congenital Anomalies, Pediatric Department 2, HER, CHU IBN SINA, Rabat, Morocco. ${ }^{6}$ Center of consultations and external explorations, HER, CHU IBN SINA, Rabat, Morocco.

Received: 7 November 2019 Accepted: 27 May 2020 Published online: 03 June 2020

\section{References}

1. REMERA: Registre des malformations en Rhône Alpes, Situation du registre en 2011, Rapport d'activités. Données naissances 2010

2. Les malformations congénitales en Rhône-Alpes: Les dossiers santéenvironnement de l'ors Août 2012 - n8, Observatoire Régional de la Santé Rhône-Alpes. http://www.ors-auvergne-rhone-alpes.org.

3. Hatton F, Bouvier-Colle MH, Blondel B, Pequignot F, Letoullec A. Evolution de la mortalité infantile en France: fréquence et causes de 1950 à 1997. Arch Pédiatr. 2000;7:239-44. https://doi.org/10.1016/s0929-693x(00)89004-1.

4. Lee K, Khoshnood B, Chen L, Wall SN, Cromie WJ, Mittendor RL. Infant mortality from congenital malformations in the United States, 1970-1997. Obstet Gynecol. 2001;98:620-9.

5. Liu S, Joseph KS, Kramer MS, Allen AC, Sauve R, Rusen ID, Wen SW. Fetal and infant health study Group of the Canadien Perinatal Surveillance system. Relationship of prenatal diagnosis and pregnancy termination to overall infant mortality in Canada. JAMA. 2002;287:1561-7.

6. Waitzman NJ, Romano PS, Scheffler RM. Estimates of the economic costs of birth defects. Inquiry. 1994;31:188-205.

7. Stevenson RE. Human Malformations and related anomalies. New York: New York University Press; 1993. p. 115.

8. Enquête Nationale sur la Population et la Santé Familiale (ENPSF). Rapport Préliminaire. Rabat: Ministère de la Santé, DPRF/DPE/SEIS; 2018.

9. Bérénice DORAY. Epidémiologie, clinique, génétique et prévention des malformations congénitales, Registre des malformations congénitales d'Alsace 1995-2009. Thèse, Université de Strasbourg, ECOLE DOCTORALE des sciences de la vie et de la santé, 25 Juillet 2013.

10. Lelong N, Thieulin A-C, Vodovar V, Goffinet F, Khoshnood B. Surveillance épidémiologique et diagnostic prénatal des malformations congénitales en population parisienne: évolution sur 27 ans, 1981-2007. Arch Pediatr. 2012; 19:1030-8. https://doi.org/10.1016/j.arcped.2012.06.021.

11. Pathologie du développement: malformations congénitales 2011-2012. Collège Français des Pathologistes (CoPath). http://www.campus.cerimes.fr.

12. CIM-10 FR, Classification Statistique Internationale des Maladies et des Problèmes de santé connexes. Rapport de la conférence internationale, volume 1, édition 2017.

13. Toni LK. ETUDE DES MALFORMATIONS CONGENITALES CLINIQUEMENT VISIBLES A LA NAISSANCE A LUBUMBASHI. Mémoire, Université de Lubumbashi, Faculté de Médecine, année; 2010-2011.

14. Tabu G. Profil des malformations congénitales apparentes à Kinshasa. Mémoire de Spécialisation: Université de Kinshasa; 2004. https://www. facmed-unikin.net/tfe-memoires-articles-depuis-1960-a-la-faculte-demedecine/.

15. Shawky RM, Sadik DI. Congenital malformations prevalent among Egyptien children and associated risk factors. Egyptian J Med Hum Genet. 2011;12: 69-78. https://doi.org/10.1016/j.ejmhg.2011.02.016.

16. De Vigan C, Khoshnood B, Cadio E, Vodovar V, Goffinet F. Le Registre des malformations de Paris: un outil pour la surveillance des malformations et l'évaluation de leur prise en charge. Inserm, UMR S149, IFR 69, Unité de recherche épidémiologique en santé périnatale et santé des femmes, Paris, France. Paris. BEH thématique 28-29 / 8 juillet: UPMC, Université Paris 6, UMR S149; 2008

17. Taylor G. Les anomalies congénitales au CANADA 2013, Rapport de surveillance sur la santé périnatale. Ottawa: Agence de la santé publique du CANADA; 2013.

18. Le MT, Shumate CJ, Hoyt AT, Wilkinson AV, Canfield MA. The prevalence of birth defects among non-Hispanic Asian/Pacific islanders and American
Indians/Alaska natives in Texas, 1999-2015. Birth Defects Res. 2019:1-9. https://doi.org/10.1002/bdr2.1543.

19. Penchaszadeh VB. Preventing congenital anomalies in developing countries. Community Genet. 2002;5:61-9. https://doi.org/10.1159/000064632.

20. Ameen SK, Alalaf SK, Shabila NP. Pattern of congenital anomalies at birth and their correlations with maternal characteristics in the maternity teaching hospital, Erbil city, Iraq. BMC Pregnancy Childbirth. 2018;18:501. https://doi.org/10.1186/s12884-018-2141-2.

21. Soudabeh V, Mina J, Samaneh S, Mina A, Mohammad M. Prevalence of congenital anomalies in Iran: A review article. Iran J Public Health. 2017; 46(6):733-43.

22. Vishnu Bhat B, Babu L. Congenital malformations at birth - A prospective study from south India. Indian J Pediatr. 1998;65:873-81.

23. Sarkar S, Patra C, Dasgupta MK, et al. Prevalence of congenital anomalies in neonates and associated risk factors in a tertiary care hospital in eastern India. J Clin Neonatol. 2013;2:131-4.

24. Dolk H, Loane M, Garne E. The prevalence of congenital anomalies in Europe. Adv Exp Med Biol. 2010:349-64. https://doi.org/10.1007/978-90-4819485-8_20.

25. Bhide $\mathrm{P}, \mathrm{Kar}$ A. A national estimate of the birth prevalence of congenital anomalies in India: systematic review and meta-analysis. BMC Pediatrics. 2018:18:175. https://doi.org/10.1186/s12887-018-1149-0.

26. Himmetoglu MB, Tiras RG, Karabacak O, Sahin I, Onan A. The incidence of congenital malformations in a Turkish population. Int J Gynecol Obstet. 1996;55:117-21.

27. Taye M, Afework M, Fantaye W, Diro E, Worku A. Congenital anomalies prevalence in Addis Ababa and the Amhara region, Ethiopia: a descriptive cross-sectional study. BMC Pediatrics. 2019;19:234. https://doi.org/10.1186/ s12887-019-1596-2.

28. Morris JK, Rankin J, Draper ES, Kurinczuk JJ, Springett A, Tucker D, Wellesley D, Wreyford B, Wald NJ. Prevention of neural tube defects in the UK: a missed opportunity. Arch Dis Child. 2016;101:604-7. https://doi.org/10.1136/ archdischild-2015-309226.

29. https://eu-rd-platform.jrc.ec.europa.eu/eurocat/eurocat-data/prevalence_en. Accessed 20 April 2020.

30. Gimeno-Martos HS, Cavero-Carbonell C, López-Maside A, Bosch-Sánchez S, Martos-Jiménez C, Zurriaga O. Chromosomal anomalies: The experience of the Congenital Anomalies Registry of the Valencia Region. An Pediatr (Barc). 2016;84(4):203-10. https://doi.org/10.1016/j.anpedi.2015.09.010.

31. A-HM SBI, Attyyaa RA, et al. Antenatal diagnosis, prevalence and outcome of major congenital anomalies in Saudi Arabia: a hospital-based study. Ann Saudi Med. 2008;28(4):272-6. https://doi.org/10.5144/0256-4947.2008.272.

32. Onyambu CK, Tharamba NM. Screening for congenital fetal anomalies in low risk pregnancy: the Kenyatta National Hospital experience. BMC Pregnancy Childbirth. 2018;18:180. https://doi.org/10.1186/s12884-018-1824-z.

33. Stevenson RE, Hunter AGW. Considering the Embryopathogenesis of VACTERL association. Mol Syndromol. 2013;4:7-15. https://doi.org/10.1159/ 000346192.

34. Padma S, Sundaram PS, Sonik B. A case of VACTERL and non-VACTERL association without the "V and L". Indian J Nucl Med. 2014;29(I):46.

\section{Publisher's Note}

Springer Nature remains neutral with regard to jurisdictional claims in published maps and institutional affiliations.

Ready to submit your research? Choose BMC and benefit from:

- fast, convenient online submission

- thorough peer review by experienced researchers in your field

- rapid publication on acceptance

- support for research data, including large and complex data types

- gold Open Access which fosters wider collaboration and increased citations

- maximum visibility for your research: over $100 \mathrm{M}$ website views per year

At BMC, research is always in progress.

Learn more biomedcentral.com/submissions 